Journal of Agricultural Sciences
(Tarim Bilimleri Dergisi)

\title{
A Study on Milk Compositions of Hair Goat and Saanen x Hair Goat Crossbreed $\left(F_{1}\right)$ under Semi-Intensive Conditions
}

\author{
Bahattin ÇAK ${ }^{\mathrm{a}}(\mathbb{D})$, Orhan YILMAZ ${ }^{\mathrm{I}}$, Elvan OCAK ${ }^{\mathrm{b}} \mathbb{C}^{\mathrm{D}}$, Ahmet Fatih DEMIREL $^{\mathrm{a}}$ \\ ${ }^{a}$ Department of Animal Husbandry, Faculty of Veterinary Medicine, University of Van Yuzuncu Yil, Van, TURKEY \\ ${ }^{b}$ Department of Food Engineering, Faculty of Engineering, University of Van Yuzuncu Yil, Van, TURKEY \\ ARTICLE INFO \\ Research Article \\ Corresponding Author: Bahattin ÇAK, E-mail: bahattincak@yyu.edu.tr \\ Received: 15 May 2019 / Revised: 26 July 2019 / Accepted: 05 November 2019 / Online: 18 January 2021
}

\section{ABSTRACT}

This study was carried out to evaluate compositions of milk from Hair goat and Saanen $x$ Hair goat crossbreed $\left(F_{1}\right)$ under semi-intensive conditions. The research was conducted on 20 Hair goats and 20 Saanen $\mathrm{x}$ Hair goat crossbreed $\left(\mathrm{F}_{1}\right)$ at Farm for Research and Application of Van Yuzuncu Yil University in Turkey. All the experimental goats were 3 years old and were raised under semi-intensive conditions. In the current study, the average fat, non-fat solid, protein, lactose, total solids, lactic acid, $\mathrm{pH}$ values of Hair and crossbreed goat milks were $3.98 \%, 3.80 \%$; $9.54 \%, 9.24 \% ; 3.59 \%, 3.48 \% ; 5.24 \%, 5.08 \% ; 13.51 \%, 13.04 \% ; 0.24 \%$, $0.25 \% ; 6.62,6.64$, respectively. Lactation stage had a significant influence $(\mathrm{P}<0.05 ; \mathrm{P}<0.001)$ on milk fat, non-fat solid, protein, lactose, total solids contents and lactic acid value in Hair and crossbreed goats' milk. Also, genotype had a significant influence $(\mathrm{P}<0.001)$ on non-fat solid, protein, lactose and total solids contents of the milk. In conclusion, Hair goats and crossbreed goats produce milk with a variable milk fat, non-fat solid, protein, lactose, total solids contents at the different stages of lactation. The mean values of milk non-fat solid, protein, lactose and total solids in Hair goats' milk were higher than those of crossbreed goats. Also, milk fat content, lactic acid and $\mathrm{pH}$ values in Hair and crossbreed goats' milk were similar.

Keywords: Hair goat, Saanen x Hair goat $\left(\mathrm{F}_{1}\right)$ crossbreed, Milk composition, Semi-intensive conditions

(C) Ankara University, Faculty of Agriculture

\section{Introduction}

Goat breeding is an important livestock activity for underdeveloped and developing countries due to the low cost of production. Turkey has favorable geographical characteristics and socio-economic structure for goat breeding. The goats that grown in a large part of Turkey has been contributed significantly to the agricultural economy (Turkstat 2017). Goat population are 10922 427 in Turkey and $98.11 \%$ of its are Hair goat. The annual amount of milk obtained from indigenous goat herds is approximately 561826 tons (Turkstat 2018).

The energy and nutrients that form basis of a healthy life need to be consumed in quantities needed by consumed foods. Adequate and balanced nutrition plays an important role in protection of growth, development and health of the individual. One of the four basic food groups that need to be taken every meal is milk and dairy products. Milk which is a good food in terms of other nutrients except for Vitamin C and iron is necessary for every period of human life (Çak \& Demirel 2018).

Goat milk consumption supplies well and balanced nutrition for the children. The symptoms of allergies to cow milk may disappear with goat milk consumption for the children (Merin et al. 1988). The chemical composition of milk of animal species differs (Rezaei et al. 2016). Components like fat and protein in milk are significant both the dairy industry and human nutrition. The nutritional value of milk is tightly interested in its composition, which is influenced by factors such as breed, feeding, lactation stage, season, etc. (Abdelsalam et al. 2000). Variability of milk production is largely affected by nutrition (Min et al. 2005). One of the major factors that affect milk yield and composition is the stage of lactation. There are three main stages of lactation namely early, mid and late lactation (Idowu \& Adewumi 2017). Mioč et al. (2008) reported that Saanen breed had higher daily and lactation milk yield but lower percentage of milk constituents than Alpine breed. Fat and protein increased with advancing stage of lactation, while lactose had a reverse trend. Ciappesoni et al. (2004) found that milk protein of Czech White Shorthaired Goats was significantly influenced by effect of stage of lactation. 
There has been an increasing interest towards goats' milk and its products in Turkey in recent years. However, studies on milk compositions of pure and crossbreed goats, in Turkey and similar agroecological zones, are limited. Therefore, further researches are needed to evaluate milk components of pure and crossbreed goats in these zones.

This research was carried out to evaluate compositions of milk from Hair goat and Saanen $\mathrm{x}$ Hair goat crossbreed $\left(\mathrm{F}_{1}\right)$ under semi-intensive conditions.

\section{Material and Methods}

\subsection{Goats, shelter and management}

The research was carried out 20 Hair goats and 20 Saanen x Hair goat crossbreed $\left(\mathrm{F}_{1}\right)$ at Farm for Research and Application of Van Yuzuncu Yil University in Turkey in 2016. Van is located between $42^{\circ} 40^{\prime}$ and $44^{\circ} 30^{\prime}$ east longitudes, $37^{\circ} 43^{\prime}$ and $39^{\circ} 26^{\prime}$ north latitudes. The climatic situation of Van is hot and dried in summer, and cold and snowy in winter. In 2016 , the average annual ambient temperature and rainfall of Van were $9.5^{\circ} \mathrm{C}$ and $393.5 \mathrm{~mm}$, respectively. All the experimental goats were 3 years old. Goats were housed in semi-open sheds under semi-intensive conditions. Goats in both groups were fed $600 \mathrm{~g} / \mathrm{day}$ of concentrate (16\% crude protein and $2500 \mathrm{kcal}$ metabolizable energy per kg dry matter) and grazed on pasture during lactation.

\subsection{The analysis of milk samples}

Physical and chemical compositions of milk were defined in the $1^{\text {st }}, 2^{\text {nd }}, 3^{\text {rd }}, 4^{\text {th }}$ and $5^{\text {th }}$ months of lactation. First of milk samples were collected in March 2016. Milk samples were taken once a day at 9-10 hours in the morning and were carried on quickly to the laboratory for analysis in the cold chain. Total solids, fat content, total protein content, lactose content and lactic acidity of milk were analyzed Gravimetric method, Gerber method, Kjeldahl method, Photometric method, and Titration method respectively Kurt et al. (2003). pH was detected by a pH meter (Kosikowski 1982).

\subsection{Statistical analysis}

Descriptive statistics for studied variables (characteristics) were presented as mean and standard error of mean. Data were analyzed by two factors experiments with repeated measurements on one factor levels in GLM procedure by the following statistical model:

$$
\begin{aligned}
& \mathrm{Y}_{\mathrm{ijm}}=\mu+\alpha_{\mathrm{i}}+\pi_{\mathrm{m}(\mathrm{i})}+\beta_{\mathrm{j}}+\alpha \beta_{\mathrm{ij}}+\beta \pi_{\mathrm{jm}(\mathrm{i})}+\mathrm{e}_{1(\mathrm{ijm})} \\
& \left(\mathrm{i}=1, . . \mathrm{k} ; \mathrm{k}=2 ; \mathrm{j}=1, . ., \mathrm{p} ; \mathrm{p}=5 \text { ve } \mathrm{m}=1, . ., \mathrm{n}_{\mathrm{i}} ; \mathrm{n}=40\right)
\end{aligned}
$$

Where;

$\mathrm{Y}_{\mathrm{ijm}}$ : milk fat, non-fat solid, protein, lactose, total solids, lactic acid and $\mathrm{pH}$ values measurements on each goat

$\mu$ : overall mean,

$\alpha_{\mathrm{i}}$ : effect of the $\mathrm{i}^{\text {th }}$ goat genotype [Hair, Saanen $\mathrm{x}$ Hair goat $\left(\mathrm{F}_{1}\right)$ ],

$\pi_{\mathrm{m}(\mathrm{i})}$ : effect of the $\mathrm{i}^{\text {th }}$ goat genotype $\mathrm{m}^{\text {th }}$ random effect of the animal (error 1 )

$\beta_{\mathrm{j}}$ : effect of the $\mathrm{j}^{\text {th }}$ lactation stages

$\alpha \beta_{\mathrm{ij}}$ : interactions between genotypes and lactation stages,

$\beta \pi_{\mathrm{jm}(\mathrm{i})}$ : interactions between the animal and lactation stages in the level of the $\mathrm{i}^{\text {th }}$ goat genotype,

$\mathrm{e}_{1(\mathrm{ijm})}$ : random error.

After ANOVA, Tukey multiple comparison test was also used to identify different lactation stages. Statistical significance level was considered as 5\% and SPSS (ver. 13) statistical program was used for all statistical computations (SPSS 2006).

\section{Results and Discussion}

Effects of lactation stage, genotype and interaction between lactation stage with genotype on milk components of Hair goat and Saanen $x$ Hair goat crossbreed $\left(\mathrm{F}_{1}\right)$ are presented in Table 1 . The results of the study showed that lactation stage had a significant influence $(\mathrm{P}<0.05$ and $\mathrm{P}<0.001)$ on milk fat, non-fat solid, protein, lactose, total solids contents and lactic acid value in Hair and 
crossbreed goats' milk. Genotype had a significant influence $(\mathrm{P}<0.001)$ on non-fat solid, protein, lactose and total solids contents of milk in the $4^{\text {th }}$ month of lactation. Non-fat solid, protein, lactose and total solids contents of milk in the $4^{\text {th }}$ month of lactation had in favor of Hair goats. Also, when the overall means of milk contents in Hair goats' milk compared with those of crossbreed goats, Hair goats' milk had a higher mean value of non-fat solid, protein, lactose and total solids contents. In addition, there was significant $(\mathrm{P}<0.05)$ interaction between genotype and lactation stage on total solids content of the milk.

Milk components in lactation stages of Hair and crossbreed goats are presented in Figure 1. It is seen that considerable changes occurred according to lactation stages of milk contents in Hair and crossbreed goats' milk.

Table 1- Effect of lactation stage, genotype and interaction between lactation stage with genotype on milk components of Hair goat and Saanen $x$ Hair goat crossbreed $\left(F_{1}\right)$

\begin{tabular}{|c|c|c|c|c|c|c|c|c|c|c|}
\hline \multirow{3}{*}{$\begin{array}{c}\text { Milk } \\
\text { components }\end{array}$} & \multirow{3}{*}{$\begin{array}{l}\text { Genotype } \\
(G)\end{array}$} & \multirow{3}{*}{$n$} & \multicolumn{5}{|c|}{ Lactation Stages $(L S)$} & \multirow{3}{*}{$\begin{array}{l}\text { Significance } \\
\quad \text { of } L S\end{array}$} & \multirow{3}{*}{$\begin{array}{l}G x \\
L S\end{array}$} & \multirow{2}{*}{ Overall means } \\
\hline & & & $I^{s t}$ month & $2^{\text {nd }}$ month & $3^{r d}$ month & $4^{\text {th }}$ month & $5^{\text {th }}$ month & & & \\
\hline & & & Mean \pm SEM & Mean $\pm S E M$ & Mean \pm SEM & Mean $\pm S E M$ & Mean $\pm S E M$ & & & Mean \pm SEM \\
\hline \multirow{2}{*}{$\begin{array}{l}\text { Fat } \\
(\%)\end{array}$} & Hair goat & 20 & $4.02 \pm 0.12^{\mathrm{ab}}$ & $3.90 \pm 0.11^{\mathrm{b}}$ & $4.32 \pm 0.08^{\mathrm{a}}$ & $3.83 \pm 0.16^{\mathrm{b}}$ & $3.80 \pm 0.19^{\mathrm{b}}$ & $*$ & \multirow[b]{2}{*}{$\mathrm{ns}$} & $3.98 \pm 0.06$ \\
\hline & $\begin{array}{l}\text { Saanen } \mathrm{x} \\
\text { Hair goat }\end{array}$ & 20 & $3.95 \pm 0.15^{\mathrm{a}}$ & $4.08 \pm 0.12^{\mathrm{a}}$ & $4.35 \pm 0.07^{\mathrm{a}}$ & $3.34 \pm 0.21^{\mathrm{b}}$ & $3.30 \pm 0.19^{b}$ & $* * *$ & & $3.80 \pm 0.08$ \\
\hline \multirow{2}{*}{$\begin{array}{c}\text { Non-fat solid } \\
(\%)\end{array}$} & Hair goat & 20 & $9.31 \pm 0.09^{\mathrm{b}}$ & $9.93 \pm 0.08^{\mathrm{a}}$ & $9.26 \pm 0.07^{b}$ & $9.84 \pm 0.09^{\mathrm{a} \#}$ & $9.35 \pm 0.20^{\mathrm{b}}$ & $* * *$ & \multirow[b]{2}{*}{ ns } & $9.54 \pm 0.06^{\#}$ \\
\hline & $\begin{array}{l}\text { Saanen x } \\
\text { Hair goat } \\
\end{array}$ & 20 & $9.12 \pm 0.11^{\mathrm{b}}$ & $9.77 \pm 0.10^{\mathrm{a}}$ & $8.96 \pm 0.17^{b}$ & $9.11 \pm 0.07^{b}$ & $9.24 \pm 0.12^{b}$ & $* * *$ & & $9.24 \pm 0.06$ \\
\hline \multirow{2}{*}{$\begin{array}{l}\text { Protein } \\
(\%)\end{array}$} & Hair goat & 20 & $3.52 \pm 0.04^{\mathrm{b}}$ & $3.73 \pm 0.03^{\mathrm{a}}$ & $3.49 \pm 0.03^{\mathrm{b}}$ & $3.71 \pm 0.03^{\mathrm{a} \#}$ & $3.53 \pm 0.07^{\mathrm{b}}$ & $* * *$ & \multirow[b]{2}{*}{ ns } & $3.59 \pm 0.02^{\#}$ \\
\hline & $\begin{array}{l}\text { Saanen } \mathrm{x} \\
\text { Hair goat } \\
\end{array}$ & 20 & $3.44 \pm 0.04^{\mathrm{b}}$ & $3.69 \pm 0.05^{\mathrm{a}}$ & $3.38 \pm 0.06^{\mathrm{b}}$ & $3.43 \pm 0.02^{\mathrm{b}}$ & $3.48 \pm 0.04^{b}$ & $* * *$ & & $3.48 \pm 0.02$ \\
\hline \multirow{2}{*}{$\begin{array}{l}\text { Lactose } \\
(\%)\end{array}$} & Hair goat & 20 & $5.10 \pm 0.05^{\mathrm{b}}$ & $5.49 \pm 0.05^{\mathrm{a}}$ & $5.08 \pm 0.04^{\mathrm{b}}$ & $5.39 \pm 0.05^{\mathrm{a} \#}$ & $5.14 \pm 0.10^{\mathrm{b}}$ & $* * *$ & \multirow[b]{2}{*}{ ns } & $5.24 \pm 0.03^{\#}$ \\
\hline & $\begin{array}{l}\text { Saanen } \mathrm{x} \\
\text { Hair goat }\end{array}$ & 20 & $4.98 \pm 0.06^{\mathrm{b}}$ & $5.42 \pm 0.07^{\mathrm{a}}$ & $4.92 \pm 0.09^{\mathrm{b}}$ & $5.00 \pm 0.03^{\mathrm{b}}$ & $5.07 \pm 0.06^{\mathrm{b}}$ & $* * *$ & & $5.08 \pm 0.03$ \\
\hline \multirow{2}{*}{$\begin{array}{c}\text { Total solids } \\
(\%)\end{array}$} & Hair goat & 20 & $13.33 \pm 0.15^{\mathrm{ab}}$ & $13.83 \pm 0.12^{\mathrm{a}}$ & $13.58 \pm 0.07^{\mathrm{ab}}$ & $13.67 \pm 0.21^{\mathrm{a} \text { \# }}$ & $13.15 \pm 0.23^{b}$ & $*$ & \multirow[b]{2}{*}{$*$} & $13.51 \pm 0.08^{\#}$ \\
\hline & $\begin{array}{l}\text { Saanen } \mathrm{x} \\
\text { Hair goat }\end{array}$ & 20 & $13.07 \pm 0.15^{\mathrm{bc}}$ & $13.85 \pm 0.18^{\mathrm{a}}$ & $13.31 \pm 0.18^{\mathrm{ab}}$ & $12.45 \pm 0.23^{\mathrm{d}}$ & $12.54 \pm 0.22^{\mathrm{cd}}$ & $* * *$ & & $13.04 \pm 0.10$ \\
\hline \multirow{2}{*}{$\begin{array}{l}\text { Lactic acid } \\
(\%)\end{array}$} & Hair goat & 20 & $0.21 \pm 0.00^{c}$ & $0.23 \pm 0.01^{\mathrm{b}}$ & $0.22 \pm 0.00^{c}$ & $0.22 \pm 0.01^{\mathrm{c}}$ & $0.33 \pm 0.00^{\mathrm{a}}$ & $* * *$ & \multirow[b]{2}{*}{ ns } & $0.24 \pm 0.01$ \\
\hline & $\begin{array}{l}\text { Saanen } \mathrm{x} \\
\text { Hair goat } \\
\end{array}$ & 20 & $0.22 \pm 0.01^{\mathrm{c}}$ & $0.24 \pm 0.00^{\mathrm{b}}$ & $0.22 \pm 0.01^{\mathrm{c}}$ & $0.22 \pm 0.00^{\mathrm{c}}$ & $0.34 \pm 0.01^{\mathrm{a}}$ & $* * *$ & & $0.25 \pm 0.00$ \\
\hline \multirow{2}{*}{$\mathrm{pH}$} & Hair goat & 20 & $6.62 \pm 0.02$ & $6.62 \pm 0.02$ & $6.63 \pm 0.02$ & $6.61 \pm 0.02$ & $6.65 \pm 0.01$ & $\mathrm{~ns}$ & \multirow[b]{2}{*}{ ns } & $6.62 \pm 0.01$ \\
\hline & $\begin{array}{l}\text { Saanen } \mathrm{x} \\
\text { Hair goat }\end{array}$ & 20 & $6.56 \pm 0.03^{\mathrm{b}}$ & $6.56 \pm 0.02^{b}$ & $6.68 \pm 0.02^{\mathrm{a}}$ & $6.70 \pm 0.01^{\mathrm{a}}$ & $6.70 \pm 0.01^{\mathrm{a}}$ & $* * *$ & & $6.64 \pm 0.01$ \\
\hline
\end{tabular}

a,b,c,d ; values indicated with lowercase letters are different from other lactation stages within the same row, *; P<0.05, ***; P<0.001, ns; non-significant Values indicated with '\#' within the same column is in favor of Hair goats ( $\mathrm{P}<0.001)$, SEM; Standard error of mean

The fat content in milk varies depending on factors such as lactation period, genotype and nutrition (Haenlein 2004; Kondyli et al. 2012). In this study, it was observed that the most variable compound in the milk of both goat genotypes was fat. Throughout lactation, the fat content of Hair goat milk varied from 3.80 to $4.32 \%$; the fat content of crossbreed goat milk varied from 3.30 to $4.35 \%$. The average fat contents of Hair and crossbreed goats were 3.98 and $3.80 \%$, respectively. Fat content of Hair goat milk in this study is consistent with the value (3.93\%) reported for Hair goats by (Cak et al. 2017). Milk fat contents obtained for both goat genotypes in this study were higher than the values (2.84 and 3.72\%) reported for the Czech White Shorthaired goats by Ciappesoni et al. (2004), however, were lower than milk fat contents (4.02 and 4.70\%) reported for Damascus and Boer goats and by Güler et al. (2007) and Mestawet et al. (2012). These differences in milk fat content were probably due to genotype, feeding, management, climate, etc. conditions. Cak et al. (2017) reported that lactation stage had a significant influence on milk fat. Results which reported correspond with the results of this study. Milk fat content for both goat genotypes in the present study was lowest at the end of lactation stage. This finding is inconsistent with finding reported for Hair goats by Cak et al. (2017).

Goat milk proteins have very important differences in amino acid compositions when compared milk proteins of other mammalian species, in addition to this, the relative proportions of the various milk proteins differ in goat and cow milk (Monaci et al. 2006). The protein content of milk is very important in cheese production. In this study, throughout lactation, the protein content of Hair goat milk varied from 3.49 to $3.73 \%$; the protein content of crossbreed goat milk varied from 3.38 to $3.69 \%$. The protein content of both goat genotypes was significantly influenced by the lactation stage. The average protein contents of Hair and crossbreed goats were 3.59 and $3.48 \%$, respectively. Protein contents of Hair and crossbreed goat milks in this research were higher than the value (3.45\%) notified for Hair goats by Cak et al. (2017), however, were lower than the values (4.05\%) notified 
for Boer goats and by Mestawet et al. (2012). These differences in milk protein content were probably due to genotype, feeding, management, climate, etc. conditions.

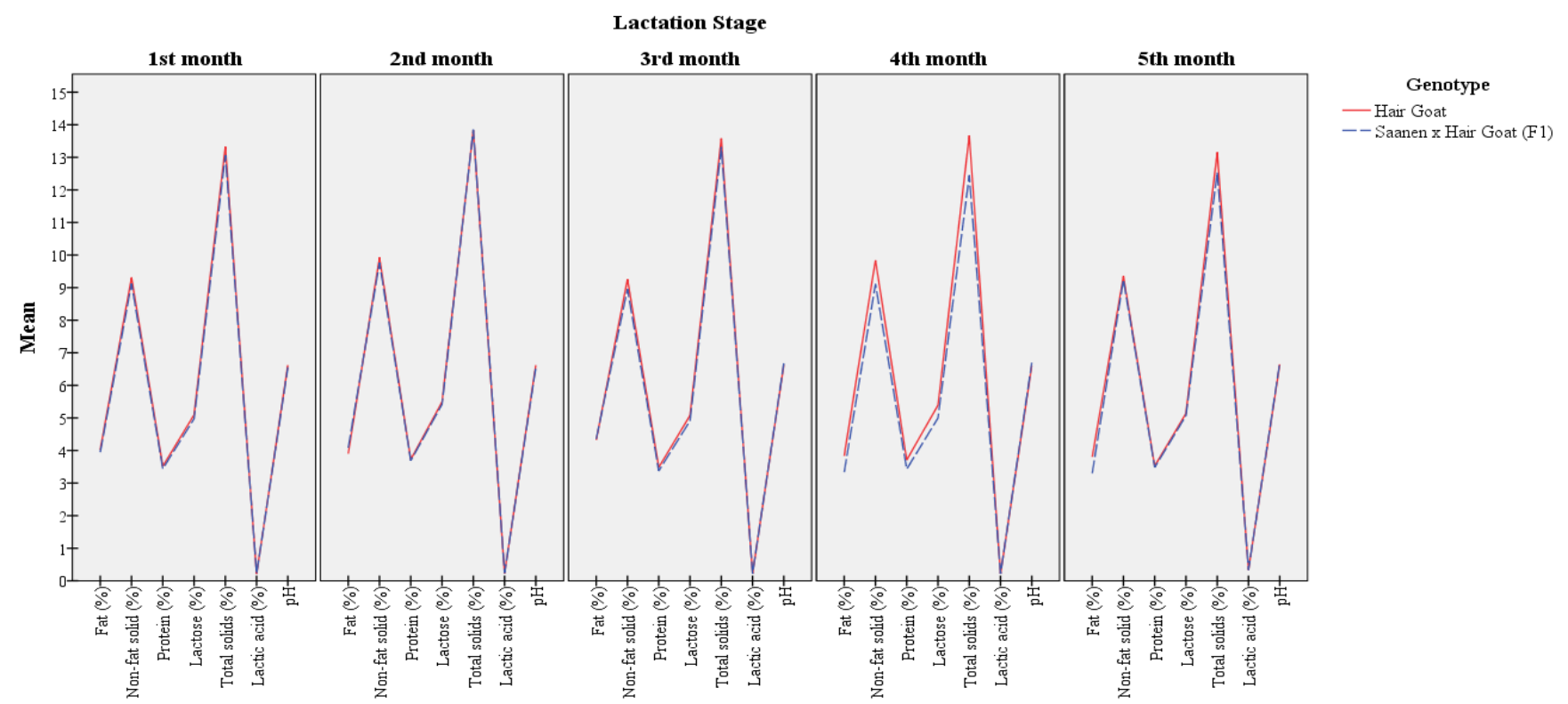

Figure 1- Changes in milk components according to lactation stages in goat genotypes

Total solids are important for nutritional value of milk and processing of products. In the current study, throughout lactation, the total solids content of Hair goat milk varied from 13.15 to 13.83; the total solids content of crossbreed goat milk varied from 12.45 to $13.85 \%$. The content of total solids in milk of both goat genotypes statistically differed in lactation stages. However, the effect of lactation stage on total solids in the milk found the non-significant by Addass et al. (2013). The mean total solids contents of Hair and crossbreed goat milks were 13.51 and $13.04 \%$, respectively. The content of total solids obtained for Hair goat milk in the present study was higher than the values (13.07 and 12.2\%) reported for Hair and Damascus goats (Keskin et al. 2004; Cak et al. 2017). The content of total solids in crossbreed goat milk was similar to the value reported for Hair goats by Cak et al. (2017), however, was higher than the value notified for Damascus goats by Keskin et al. (2004).

In this study, lactose content was different in the early and late lactation stages of both Saanen $\mathrm{x}$ Hair goat and Hair goat genotype. Conversely, Cak et al. (2017) reported that it was similarity in the early and late lactation stages. Also, Mestawet et al. (2012) and Prasad et al. (2005) notified that lactose content in the early lactation stage and the late lactation stage was highest, lowest respectively. Lactose contents of Hair and crossbreed goat milks in our study were similar to the finding (5.15\%) reported by Cak et al. (2017), were higher than the result (4.66\%) notified by Kanwal et al. (2004).

In the current study, the effect of lactation stage season on $\mathrm{pH}$ of Hair goat milk was statistically non-important, however, crossbreed goat milk was statistically significant. Addass et al. (2013) notified that the pH was not influenced by the lactation stage season.

\section{Conclusions}

The findings of the current study showed that Hair goats and crossbreed goats produce milk with a variable milk fat, non-fat solid, protein, lactose, total solids contents at the different stages of lactation. The mean values of milk non-fat solid, protein, lactose and total solids in Hair goats' milk were higher than those of crossbreed goats. These results also indicated that fat content, lactic acid and $\mathrm{pH}$ values in Hair and crossbreed goats' milk were similar.

\section{Acknowledgements}

The authors would like to thank to Scientific Research Projects Coordination Unit of Van Yuzuncu Yil University (the project number TSA-2016-5126) for financial supporting and Prof. Dr. Siddık KESKIN for statistical analysis.

\section{References}

Abdelsalam M, Eissa M, Maharm G \& Heider A (2000). Improving the productivity of the Barki goat by crossbreeding with Damascus or Zaraibi breeds. Alexandria Journal of Agricultural Research 45(3): 33-42 
Addass P, Tizhe M, Midau A, Alheri P \& Yahya M (2013). Effect of genotype, stage of lactation, season and parity on milk composition of goat. Annals of Biological Research 4(8): 248-252

Cak B, Yilmaz O \& Ocak E (2017). Physical-Chemical Composition of Milk and Fiber Quality in Hair Goats and the Phenotypic Correlations between Milk Composition and Fiber Traits. Pakistan Veterinary Journal 37(1): 35-38

Ciappesoni G, Pribyl J, Milerski M \& Mares V (2004). Factors affecting goat milk yield and its composition. Czech Journal of Animal ScienceUZPI (Czech Republic) 49(11): 465-473

Çak B \& Demirel A F (2018). Physical and Chemical Properties of Milk with Excellent Nutritional Source for Humans. In: H. Arapgirlioglu, A. Atik, S. Hizıroglu, R. Elliott, D. Atik, \& editörler (Eds.), The Most Recent Studies in Science and Art, Gece Kitaplı̆̆ı, Ankara, pp. 523536

Güler Z, Keskin M, Masatçioğlu T, Gül S \& Bicer O (2007). Effects of Breed and Lactation Period on Some Characteristics and Free Fatty Acid Composition of Raw Milk from Damascus Goats and German Fawn x Hair Goat B_1 Crossbreds. Turkish Journal of Veterinary and Animal Sciences 31(5): 347-354

Haenlein G (2004). Goat milk in human nutrition. Small Ruminant Research 51(2): 155-163 10.1016/j.smallrumres.2003.08.010

Idowu S T \& Adewumi O O (2017). Genetic and non-genetic factors affecting yield and milk composition in goats. Advances in Dairy Research 5(2): 175 10.4172/2329-888X.1000175

Kanwal R, Ahmed T \& Mirza B (2004). Comparative analysis of quality of milk collected from buffalo, cow, goat and sheep of Rawalpindi/Islamabad region in Pakistan. Asian Journal of Plant Sciences 3(3): 300-305

Keskin M, Avşar Y K, Biçer O \& Güler M B (2004). A comparative study on the milk yield and milk composition of two different goat genotypes under the climate of the Eastern Mediterranean. Turkish Journal of Veterinary and Animal Sciences 28(3): 531-536

Kondyli E, Svarnas C, Samelis J \& Katsiari M (2012). Chemical composition and microbiological quality of ewe and goat milk of native Greek breeds. Small Ruminant Research 103(2-3): 194-199 10.1016/j.smallrumres.2011.09.043

Kosikowski F. (1982). Cheese and Fermented Milk Foods (2nd ed.). New York: F. V. Kosikowski \& Associates.

Kurt A, Cakmakci S \& Caglar A. (2003). Guide of inspection and analysis methods in milk and milk products. Erzurum: Agricultural Faculty Press.

Merin U, Rosenthal I \& Maltz E (1988). The composition of goat milk as affected by nutritional parameters. Milchwissenschaft 43(6): 363365

Mestawet T, Girma A, Ådnøy T, Devold T, Narvhus J \& Vegarud G (2012). Milk production, composition and variation at different lactation stages of four goat breeds in Ethiopia. Small Ruminant Research 105(1-3): 176-181 10.1016/j.smallrumres.2011.11.014

Min B, Hart S, Sahlu T \& Satter L (2005). The effect of diets on milk production and composition, and on lactation curves in pastured dairy goats. Journal of Dairy Science 88(7): 2604-2615 10.3168/jds.S0022-0302(05)72937-4

Mioč B, Prpić Z, Vnučec I, Barać Z, Sušić V, Samaržija D \& Pavić V (2008). Factors affecting goat milk yield and composition. Mljekarstvo 58(4): 305-313

Monaci L, Tregoat V, van Hengel A J \& Anklam E (2006). Milk allergens, their characteristics and their detection in food: a review. European Food Research and Technology 223(2): 149-179 10.1007/s00217-005-0178-8

Prasad H, Tewari H \& Sengar O (2005). Milk yield and composition of the beetal breed and their crosses with Jamunapari, Barbari and Black Bengal breeds of goat. Small Ruminant Research 58(2): 195-199 10.1016/j.smallrumres.2004.10.002

Rezaei R, Wu Z, Hou Y, Bazer F W \& Wu G (2016). Amino acids and mammary gland development: nutritional implications for milk production and neonatal growth. Journal of animal science and biotechnology 7(1): 20 10.1186/s40104-016-0078-8

SPSS. (2006). IBM SPSS statistics version 13.0 for Windows

Turkstat (2017). Turkstat Livestock Statistic. Retrieved in May, 20, 2018 from https://biruni.tuik.gov.tr/hayvancilikapp/hayvancilik.zul

Turkstat (2018). Turkstat Livestock Statistic. Retrieved in July, 19, 2019 from http://www.tuik.gov.tr/PreTablo.do?alt_id=1002 